\title{
The Effect of Financial and Non-financial Incentives on Job Satisfaction: An Examination of Food Chain Premises in Turkey
}

\author{
Ali Erbaş ${ }^{1} \&$ Tugay Arat ${ }^{1}$ \\ ${ }^{1}$ Vocational School of Social Sciences, Selcuk University, Konya, Turkey \\ Correspondence: Ali Erbaşı, Vocational School of Social Sciences, Selcuk University, Campus of Alaeddin \\ Keykubat, Selçuklu/Konya, Turkey. Tel: 90-332-223-2293. E-mail: aerbasi@selcuk.edu.tr
}

Received: July 23, 2012

Accepted: August 10, 2012

Online Published: September 3, 2012

doi:10.5539/ibr.v5n10p136

URL: http://dx.doi.org/10.5539/ibr.v5n10p136

\begin{abstract}
The purpose of this study is to examine the effect of financial and non-financial incentives on job satisfaction, which are used in food chain premises; and to indicate the difference of employee attitudes related to job satisfaction and incentives on some demographical variables. The questionnaires prepared for this purpose are applied to eleven employees at food premises, which are currently working in food sector in Central Anatolian Region in Turkey. The data obtained from the research are analyzed via several techniques by using SPSS 15.0 program. According to the results of the analysis, a significant relation is observed between the financial and non-financial incentives and the job satisfaction of employees. When these relations are compared, the result is that the attitudes towards financial incentives have a stronger effect on job satisfaction than the attitudes towards non-financial incentives. Besides, the differences among some demographical variables (union membership, gender, income level) and the attitudes towards these incentives and job satisfaction levels are tested. This research plays an important role to provide significant data for strategical administrative institutions of food chain premises in terms of financial and non-financial incentives, job satisfaction and some demographical characteristics of the employees.
\end{abstract}

Keywords: financial incentives, non-financial incentives, job satisfaction, food chain premises

\section{Introduction}

The premises are focused on the motivational elements to increase the productivity of employees. One of the several methods used to increase the motivation of employees is the incentive application. It is very common at such premises that there are often financial and non-financial incentive applications in order to award the employees with a high performance level and to encourage the ones with lower performance levels for higher performance. The main purpose of such applications is to establish a fair management structure within the premise; to contribute to the motivations of employees as a social being and therefore to increase their productivity and efficacy by enhancing their job satisfaction levels.

Luthans (1998) divided these incentives used by the premises into two groups as financial incentives and non-financial incentives (social, consumable, visual and auditory, manipulatable, job design). Financial incentives are the financial payments made to the employees for their high performance. According to Naldöken et al. (2011: 286), the financial incentives provided for employees are listed as payment raise, premiums, profit share, economic awards, payment packages, etc.

According to Ellis and Pennington (2004), the financial incentives have a short-term effect on the motivation levels of employees although they play a critical role in their motivation. Therefore, non-financial incentives are also required to give a long-term motivational effect instead of the short-term effects of financial incentives at these premises. Non-financial incentives are listed as enabling authority, participating in the management, job enrichment, promotion, holidays, better working atmosphere (opportunity of an air-conditioning, less noise, etc.), enhancing a sense of belonging.

The success of financial incentives on the motivation of employees has long been discusses in the literature. In addition to the studies, which claim that financial incentives have a positive effect on motivation, there are also many others, which also argues that they have a very low or a negative effect. It is very important for strategical 
administrative institutions at premises to determine to what extent these incentives affect the job satisfaction levels of employees. Therefore, it is required to determine which incentives the employees accept and which others do not serve for its purpose. Moreover, public relations in the premises will get the best benefit to draw their policies by determining the relations between financial incentives, non-financial incentives and some demographical variables related to the attitudes of employees in terms of job satisfaction. In this study, the purpose is to examine the effect of financial and non-financial incentives on job satisfaction, which are used in food chain premises and to indicate the difference of employee attitudes related to job satisfaction and incentives on some demographical variables.

The remainder of this paper is organised as follows: Section 2, presents a review of some relevant literature. In Section 3, we discuss the methodology used in this paper, while Section 4 presents the results and the important findings. Finally, in Section 5, we give some conclusions and policy recommendations.

\section{Literature Review}

There are many studies in the literature, which examine the financial and non-financial incentives and their effects on several variables. For example, Al-Nsour (2012) examined the effects of financial and non-financial incentives at Jordanian university in terms of organizational performance. A significant relation was observed between financial and non-financial incentives and organizational performance in accordance with the data obtained from this study. Moreover, the study showed that financial incentives were highly regarded than non-financial incentives. Naldöken et al. (2011) examined the financial incentive application on the motivations of employees at a state hospital in terms of their performance. It was concluded in the study that the medical employees, who benefited from these financial incentives were positively motivated by this application.

Scheepers (2009) also examined the extent to which incentive systems affected the motivations of employees at information and communication technology firms. In accordance with the results of the study, an entrepreneurial reward system tends to focus on formal acknowledgement, social incentives and organizational freedom of employees to encourage corporate entrepreneurship. Pouliakas (2008) tested the non-monotonic effect of monetary incentives on job satisfaction. In the study, 1998-2005 of the British Household Panel Survey was used to investigate the ceteris paribus association between the intensity of bonus/profit-sharing payments and the utility derived from work. According to the findings of the study, small amounts of financial incentives resulted a highly important effect on employee satisfaction, whereas large amounts of financial incentives affect them positively. Therefore, the researcher suggested no financial incentive unless sufficient amount of financial incentives were provided. Pinar et al. (2008) conducted surveys to 796 blue-collar employees at several institutions in order to determine the elements, which affect the job satisfaction of employees. According to the findings of the study, the most affected dimension in terms of job satisfactions of blue-collar employees was the job itself, and the second dimension was the payment and promotions.

Arnolds and Venter (2007) made an effort to determine the factors, which affected the motivations of blue-collar employees at manufacturing and clothing retail firms. According to the findings of the study, the most important individual motivational reward for blue-collar employees is paid holidays and for frontline employees, retirement plans. The most important motivational reward category for both blue-collar and frontline employees is fringe benefits (paid holidays, sick leave and housing loans). McDonald et al. (2007) examined the effects of financial incentives on the quality of care on practice organization, clinical autonomy, and internal motivation of doctors and nurses working in primary care.

Alwabel (2005) examined the role of financial and non-financial incentives in terms of increasing the performance of security officers during pilgrimage in their points of view. Kaya (2007) determined the factors affecting job satisfaction levels of employees at hotel managements. According to the results of the study, the most important factors affecting the job satisfaction levels were determined as the officers, physical and non-physical factors of its own nature and communication and integrity respectively. Based on these findings, the conclusion was that non-financial incentives were more effective then financial incentives in terms of the attitudes of employees.

According to the results of Career and Qualification Principles Survey conducted by the United States of America Career and Qualification Principles in 2005, it was determined that the most important element motivating both the employees and employers were job satisfaction and personal satisfaction for both groups. According to the results of the study, the financial incentives are placed as $8^{\text {th }}$ and $12^{\text {th }}$ in the sequence of elements affecting the motivation. In other words, non-financial incentives are given much importance than financial incentives (Coşkun \& Dulkadiroğlu, 2009: 89). Ağırbaş et al. (2005) examined to what extent the head physicians assistants working at hospitals are satisfied by the motivational tools applied in the hospitals and if available motivational tools have an 
important effect on job satisfaction. In the study, it is seen that no motivational tool provides the expectations of physician managers. It is also concluded in the study that such factors as the decrease of dismissal risk, improving the situations like promotion and appreciation and improving work place opportunities have significant and important effects on job satisfaction statistically.

Burgess and Ratto (2003) reviewed the incentive pay to improve public-sector efficiency and the evidence on its effects. The researchers concluded how optimal incentives for public sector differ from private sector and which types of incentives are the most appropriate for public sector. Moreover, the researchers commented on the design of new policies being introduced in the UK public sector in the light of the theoretical arguments and the evidence. Öztürk and Dündar (2003) made an effort to determine the relation between the factors, which motivate the public employees and professional variables at those institutions. According to the findings obtained in the research, it is seen that managers are more motivated by non-financial incentives than financial incentives in public employees; and employees are more motivated by financial incentives than non-financial incentives. Almost all of the public employees state that the appreciation of the actions completed create a feeling of satisfaction and give a positive motivation towards their job. It is also stated that giving an opportunity for promotion of employees and getting their opinions of their area of interest are among the important factors to motivate them for their jobs. Kitapç1 and Sezen (2002) investigated the variables, which affect job satisfaction of employees according to their career period. Based on the results of the study, it is seen that the employees with different career periods have also different job satisfaction levels in terms of different variables. According to the findings of the study, the job satisfaction levels of employees in pre-professional trial period (18-24 age group) are affected by working conditions, training given by the premise and payment. Besides, according to the results of the study, the job satisfaction levels of employees in starting and progressing professional period (26-44 age group) are affected by working conditions, connections with colleagues and manager and in the stationery period (45 and above age group) by connections with managers and participatory management.

Al-Angari (1999) examined the effects of incentive applications on the performances of employees in Riyadh Region Governorate. The researcher emphasized in the study that positive financial incentives do not satisfy the employees. Al-Wathnani (1998) also examined the impact of incentives on the efficiency of work performance and job satisfaction in security organizations. According to the findings of the study, the most valued incentives by the employees are promotions, financial allowances, leaves, allowances for medical treatment and participation in decision making. The least valued incentives by the employees are verbal appraisal, letters of thanks and financial allowances for work at distant and isolated areas. Again, according to the results of the study, the most important incentive among all is the financial ones. Besides, non-financial incentives are also determined to be effective on the increase of performance and job satisfaction.

Al-Johani (1997) made an assessment on the incentive system used at their institutions including the opinions of employees at Jeddah Migration Office. According to the findings of the study, it is emphasized that there is no great difference among the opinions of employees in terms of incentives and the most important incentives are financial incentives and then promotion. Hermalin and Weisbach (1991) examined the effect of administrative structure and direct incentives on company performance. Hilman (1987) examined the effects of financial incentives at medical institutions in terms of attitudes of doctors and their service. The researcher determined as a result of the analysis by taking the opinions of 302 doctors into consideration that financial incentives have important effects on the attitudes of doctors and service quality. Ryan et al. (1986) examined the effects of financial incentives in terms of controlling expenditures. Solt and Miller (1985) examined the effect of administrative incentives on financial performance in terms of real-estate investment partnerships. Grossman and Hart (1982) determined that the incentive effects of the threat of bankruptcy on the quality of management in a widely held corporation.

\section{Materials and Methods}

This study has a descriptive scanning model, which aims to indicate the difference in terms of some demographical characteristics on the attitudes of employees related to incentives and job satisfaction, also to examine the effect of financial and non-financial incentives applied at wholesale purchase premises in food sector on job satisfaction. The research model prepared for this purpose is given in Figure 1. 


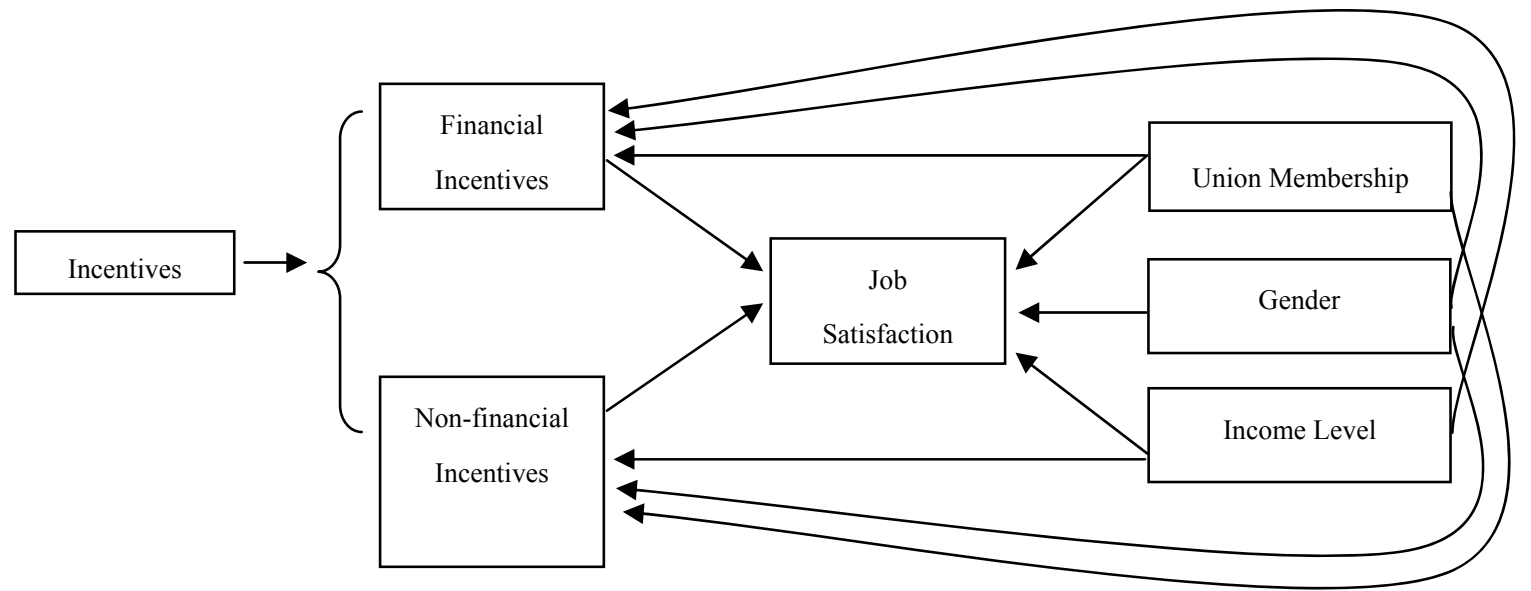

Figure 1. The Model of the Study

There are 12 hypotheses prepared to examine these according to the research model and shown in Table 1.

Table 1. Research Hypotheses

\begin{tabular}{|c|c|}
\hline Hyp. No & Hypothesis \\
\hline 1 & $\begin{array}{l}\text { There is a significant relation between the financial incentives used at food chain premises and job satisfaction levels of } \\
\text { employees. }\end{array}$ \\
\hline 2 & $\begin{array}{l}\text { lere is a significant relation between the non-financial incentives used at food chain premises and job satisfaction levels of } \\
\text { ployees. }\end{array}$ \\
\hline 3 & e financial incentives used in food chain premises affect job satisfaction more than non-financial incentives. \\
\hline 4 & $\begin{array}{l}\text { ne attitudes of employees working in food chain premises have a significant difference according to their union membership } \\
\text { atus in terms of financial incentives. }\end{array}$ \\
\hline 5 & $\begin{array}{l}\text { e attitudes of employees working in food chain premises have a significant difference according to their union membership } \\
\text { tus in terms of non-financial incentives. }\end{array}$ \\
\hline 6 & $\begin{array}{l}\text { e job satisfaction levels of employees working in food chain premises has a significant difference in terms of their union } \\
\text { mbership status. }\end{array}$ \\
\hline 7 & $\begin{array}{l}\text { The attitudes of employees working in food chain premises have a significant difference according to their gender in terms of } \\
\text { financial incentives. }\end{array}$ \\
\hline 8 & $\begin{array}{l}\text { The attitudes of employees working in food chain premises have a significant difference according to their gender in terms of } \\
\text { non-financial incentives. }\end{array}$ \\
\hline 9 & $\begin{array}{l}\text { The attitudes of employees working in food chain premises have a significant difference according to their gender in terms of job } \\
\text { satisfaction. }\end{array}$ \\
\hline 10 & $\begin{array}{l}\text { The attitudes of employees working in food chain premises have a significant difference according to their income levels in terms } \\
\text { of financial incentives. }\end{array}$ \\
\hline 11 & $\begin{array}{l}\text { The attitudes of employees working in food chain premises have a significant difference according to their income levels in terms } \\
\text { of non-financial incentives. }\end{array}$ \\
\hline 12 & The attitudes of employees working in food chain premises have a significant difference according to their income levels. \\
\hline
\end{tabular}

In the study, a field research is used to test these hypotheses. The context of the study involves the chain premises currently running their business at food sector in Central Anatolia Region in Turkey. 432 persons, working and selected randomly in eleven chain premises within the context (Adese, Sincap, Beğendik, Makromarket, Bim, A101, Migros, Akyurt, Kavruk, Kipa, Tansaş) are taken as sample.

A survey form involving four main parts and 43 questions in total is prepared in order to make a suitable investigation for the purpose of this study. The first part of the survey involves seven questions on the attitudes of employees in terms of financial incentives and the second part involves nine questions to determine the attitudes of employees in terms of non-financial incentives. In the third part, twenty questions are prepared to determine the job satisfaction levels of the employees. Seven questions are prepared to determine the demographical characteristics of participants in the fourth and last parts of the survey form. The questions in the first and second parts of the survey, which are about financial and non-financial incentives of the employees, are taken from the survey that is prepared by Al-Nsour (2012) as a result of an extensive literature review and translated into Turkish 
by the researchers. The twenty questions in the third part, which aims to determine the job satisfaction levels of the employees, are taken from the Minnesota Job Satisfaction Scale. The responses in the scale are arranged as 5-point Likert type scale. The assessments are prepared as 5 for "Strongly Agree" and 1 for "Strongly Disagree". The survey form is consulted by an expert and put into practice in the sector after making necessary alterations where seen appropriate. Before the research, a pilot application $(n=60)$ is realized at institutions of issue and validity and reliability analysis of the scales are made. The survey is calculated in terms of Cronbach Alpha values for each part and in general and also shown in Table 2. The Cronbach Alpha values obtained indicate that the survey form and all parts have a sufficient reliability. Field research is held by face-to-face interviews with 432 participants in February and March 2012. The data obtained from the study are analyzed through various techniques in SPSS 15.0 program. Only four of the surveys are not taken into consideration as they are thought to be repetitive.

Table 2. Reliability Coefficients

\begin{tabular}{ll}
\hline Survey Parts & Cronbach Alfa Reliability Coefficients \\
\hline First Part: Financial Incentives & 0.68 \\
Second Part: Non-financial Incentives & 0.71 \\
Third Part: Job Satisfaction & 0.83 \\
All Scale & 0.88 \\
\hline
\end{tabular}

\section{Findings}

Demographical information on the participants in the study is given in Table 3.

Table 3. Demographical Information on the Participants

\begin{tabular}{|c|c|c|c|c|c|}
\hline Demographic Characteristics & $n=428$ & $\%$ & Demographic Characteristics & $n=428$ & $\%$ \\
\hline Gender & & & Union Membership & & \\
\hline Male & 244 & 57.0 & Yes & 86 & 20.1 \\
\hline Female & 184 & 43.0 & No & 342 & 79.9 \\
\hline Marital Status & & & Education & & \\
\hline Married & 142 & 33.2 & Primary & 66 & 15.4 \\
\hline Single & 286 & 66.8 & Secondary & 211 & 49.3 \\
\hline Age & & & Two-year & 75 & 17.5 \\
\hline $18-25$ & 164 & 38.3 & Undergraduate & 57 & 13.3 \\
\hline $26-35$ & 202 & 47.2 & Postgraduate & 19 & 4.5 \\
\hline $36-49$ & 54 & 12.6 & Monthly Income & & \\
\hline 50 and above & 8 & 1.9 & Less than $750 \mathrm{TRY}$ & 135 & 31.6 \\
\hline Working Years in the Institution & & & 751-1000 TRY & 166 & 38.9 \\
\hline Less than a year & 130 & 30.4 & 1001-1500 TRY & 61 & 14.3 \\
\hline $1-3$ years & 156 & 36.4 & 1501-2500 TRY & 32 & 7.5 \\
\hline $4-7$ years & 83 & 19.4 & 2501-5000 TRY & 31 & 7.3 \\
\hline $8-11$ years & 41 & 9.6 & 5000 TRY and above & 2 & 0.5 \\
\hline 12 years and above & 18 & 4.2 & & & \\
\hline
\end{tabular}

Table 4 indicates the attitudes of participants in the study in terms of financial incentives; Table 5 , the attitudes towards non-financial incentives and Table 6, mean and standard deviation values in terms of job satisfaction.

Table 4. Attitudes on Financial Incentives

\begin{tabular}{|c|c|c|}
\hline$n=426$ & S.S. & $\bar{X}$ \\
\hline It provides enough payment to meet the requirements of life. & 1.0613 & 3.91 \\
\hline It provides rewards for skilled employees commensurate with their performance. & 1.0864 & 3.31 \\
\hline It provides bonuses for workers according to their post and consistent with their level of performance. & 1.1215 & 3.59 \\
\hline It provides overtime payment to employees after working hours. & 1.1263 & 3.55 \\
\hline It provides transportation allowances for those who live in far areas. & 1.1227 & 3.34 \\
\hline It provides a fair and adequate compensation on retirement. & 0.9785 & 3.31 \\
\hline It provides financial incentives to employees when they work professionally (Appropriate job qualifications). & 1.0895 & 3.26 \\
\hline Average Attitudes on Financial Incentives & 0.6831 & 3.47 \\
\hline
\end{tabular}


Table 5. Attitudes on Non-financial Incentives

\begin{tabular}{llc}
\hline $\boldsymbol{n}=\mathbf{4 2 8}$ & S.S. & $\bar{X}$ \\
\hline It ensures appropriate social security and health insurance for employees. & 0.8526 & 4.37 \\
It is keen to give a fair opportunity for employees in complaints and suggestions. & 1.0343 & 3.62 \\
It provides appropriate offices and well-furnished ones for employees. & 1.1160 & 3.37 \\
It gives smooth annual leave for employees in accordance with rules and regulations. & 1.0157 & 3.82 \\
Health insurance granted covered all members of the employees' family. & 1.1399 & 3.68 \\
Disciplinary sanctions for employees characterized by a just and objective rules. & 1.0887 & 3.27 \\
It allows career opportunities and development for employees. & 0.9997 & 3.37 \\
It holds annual ceremony in honor of creative employees. & 1.2004 & 3.10 \\
It grants certificates of appreciation and recognition of efficient employees. & 1.1989 & 3.18 \\
Average Attitudes on Non-financial Incentives & 0.5520 & 3.54 \\
\hline
\end{tabular}

Table 6. Attitudes on Job Satisfaction

\begin{tabular}{|c|c|c|}
\hline $\begin{array}{l}n=426 \\
\text { On my present job, this is how I feel about ... }\end{array}$ & S.S. & $\bar{X}$ \\
\hline Being able to keep busy all the time. & 1.0542 & 3.80 \\
\hline The chance to work alone on the job. & 0.9289 & 3.64 \\
\hline The chance to do different things from time to time. & 1.0192 & 3.69 \\
\hline The chance to be "somebody" in the community. & 1.0554 & 3.58 \\
\hline The way my boss handles his/her workers. & 1.1203 & 3.54 \\
\hline The competence of my supervisor in making decisions. & 1.1099 & 3.54 \\
\hline Being able to do things that don't go against my conscience. & 1.1458 & 3.46 \\
\hline The way my job provides for steady employment. & 1.0958 & 3.66 \\
\hline The chance to do things for other people. & 1.0517 & 3.74 \\
\hline The chance to tell people what to do. & 1.1063 & 3.44 \\
\hline The chance to do something that makes use of my abilities. & 1.0624 & 3.59 \\
\hline The way company policies are put into practice. & 1.1097 & 3.55 \\
\hline My pay and the amount of work I do. & 1.1872 & 3.28 \\
\hline The chances for advancement on this job. & 1.1660 & 3.26 \\
\hline The freedom to use my own judgment. & 1.1040 & 3.37 \\
\hline The chance to try my own methods of doing the job. & 1.0885 & 3.40 \\
\hline The working conditions. & 1.0926 & 3.39 \\
\hline The way my co-workers get along with each other. & 1.1565 & 3.62 \\
\hline The praise I get for doing a good job. & 1.1061 & 3.35 \\
\hline The feeling of accomplishment I get from the job. & 1.2832 & 3.50 \\
\hline Average Attitudes on Job Satisfaction & 0.5258 & 3.52 \\
\hline
\end{tabular}

Correlation Analysis is used to determine the relation between the attitudes on financial incentives of employees in the study and attitudes on job satisfaction and the data obtained are given in Table 7. Therefore, a high-level positive and significant relation is seen between financial incentives and job satisfaction $(\mathrm{r}=0.369, \mathrm{p}<0.01)$.

Table 7. The Relation between Financial Incentives and Job Satisfaction

\begin{tabular}{lll}
\hline & Financial Incentives & Job Satisfaction \\
\hline Pearson Correlation & 1.000 & $.369(* *)$ \\
$\mathrm{p}$ & & .000 \\
$\mathrm{n}$ & 428 & 428 \\
\hline
\end{tabular}

Note: $* * \mathrm{p}<0.01$.

Correlation Analysis is used to determine the relation between the attitudes on financial incentives of employees in the study and attitudes on job satisfaction and the data obtained are given in Table 8. Therefore, a high-level positive and significant relation is seen between financial incentives and job satisfaction $(r=0.467, p<0.01)$. 
Table 8. The Relation between Non-financial Incentives and Job Satisfaction

\begin{tabular}{lll}
\hline & Non-financial Incentives & Job Satisfaction \\
\hline Pearson Correlation & 0.765 & $.467(* *)$ \\
$\mathrm{p}$ & & .008 \\
$\mathrm{n}$ & 428 & 428 \\
\hline
\end{tabular}

Note: $* * \mathrm{p}<0.01$.

In the following sections of the study, the attitudes of participants in terms of financial incentives, non-financial incentives and the ones on job satisfaction are determined if they differ in accordance with some demographical characteristics. In this scope, Independent Samples T-test is used to determine if the union membership status of the participants make a difference on the attitudes of incentive and job satisfaction. T-test results are given in Table 9. According to this, the attitudes on financial incentives have no significant difference in terms of union membership status; but the attitudes on non-financial incentives have a significant difference in terms of union membership status $(\mathrm{t}(428)=3.75, \mathrm{p}<0.05)$. The attitudes on non-financial incentives by the employees, who have a union membership ( $\bar{X}=3.69$ ) is more positive than the ones, who have no union membership ( $\bar{X}=3.34)$. The job satisfaction levels in terms of union membership status indicate no significant difference.

Table 9. Incentive Attitudes and Job Satisfaction in terms of Union Membership Status

\begin{tabular}{lllll}
\hline Financial Incentives & $\mathbf{n}$ & $\bar{X}$ & $\boldsymbol{t}$ & $\boldsymbol{p}$ \\
\hline Those union members & 86 & 3.40 & 1.071 & 0.285 \\
Non-union members & 340 & 3.48 & & \\
\hline Non-financial Incentives & $\mathbf{n}$ & $\bar{X}$ & $\mathbf{t}$ & $\mathbf{p}$ \\
\hline Those union members & 86 & 3.34 & 3.752 & $0.012^{*}$ \\
Non-union members & 342 & 3.69 & & \\
\hline Job Satisfaction & $\mathbf{n}$ & $\bar{X}$ & $\mathbf{t}$ & $\mathbf{p}$ \\
\hline Those union members & 86 & 3.48 & -0.697 & 0.486 \\
Non-union members & 340 & 3.53 & & \\
\hline
\end{tabular}

Note: ${ }^{*} \mathrm{p}<0.05$.

Independent Samples T-test is used to determine if there is a significant in terms of gender on the financial incentives, non-financial incentives and job satisfaction levels of employees participated in the study. T-test results are indicated in Table 10. According to this, the attitudes of employees on financial incentives have a significant difference in terms of gender $(\mathrm{t}(426)=1.071, \mathrm{p}<0.05)$. The attitudes of male employees on financial incentives $(\bar{X}$ $=3.52$ ) are more positive than female employees $(\bar{X}=3.39)$. The attitudes of employees on non-financial incentives have no significant difference in terms of gender. The attitudes of employees on job satisfaction have a significant difference in terms of gender ( $\mathrm{t}(426)=-2.668, \mathrm{p}<0.05)$. According to this, the job satisfaction levels of female employees $(\bar{X}=3.60)$ are higher than male employees $(\bar{X}=3.46)$.

Table 10. Incentive Attitudes and Job Satisfaction in terms of Gender

\begin{tabular}{lllll}
\hline Financial Incentives & $\mathbf{n}$ & $\bar{X}$ & $\boldsymbol{t}$ & $\boldsymbol{p}$ \\
\hline Male & 244 & 3.52 & 1.071 & $0.029^{*}$ \\
Female & 182 & 3.39 & & \\
\hline Non-financial Incentives & $\mathbf{n}$ & $\bar{X}$ & $\mathbf{t}$ & $\mathbf{p}$ \\
\hline Male & 244 & 3.56 & 3.752 & 0.351 \\
Female & 184 & 3.51 & & $\mathbf{p}$ \\
\hline Job Satisfaction & $\mathbf{n}$ & $\bar{X}$ & $\mathbf{t}$ & $0.008^{*}$ \\
\hline Male & 244 & 3.46 & -2.668 & \\
Female & 182 & 3.60 & & \\
\hline
\end{tabular}

Note: ${ }^{*} \mathrm{p}<0.05$.

One-dimensional analysis of variance is used to determine if there is a difference in terms of income levels on incentive attitudes and job satisfaction levels of employees participated in the study. According to the results of the analysis as seen in Table 11, there is a significant difference at all income levels in terms of financial incentive attitudes $\left(\mathrm{F}_{5-421}=6.706 ; \mathrm{p}<0.05\right)$, non-financial incentive attitudes $\left(\mathrm{F}_{5-423}=4.055 ; \mathrm{p}<0.05\right)$ and job satisfaction 
attitudes $\left(\mathrm{F}_{5-421}=2.662 ; \mathrm{p}<0.05\right)$ among every group. Scheffe test is used to determine among which groups there is an interdivisional difference. According to this, the difference is observed at income level groups of 5000 TRY and above, 750 TRY and below and 751-1000 TRY and 1001-1500 TRY.

Table 11. Incentive Attitudes and Job Satisfaction in terms of Income Level

\begin{tabular}{|c|c|c|c|c|c|}
\hline & Sum of Squares & $S d$ & Mean Square & $\boldsymbol{F}$ & $p$ \\
\hline \multicolumn{6}{|c|}{ Financial Incentives } \\
\hline Intergroup & 12.827 & 5 & 2.565 & & \\
\hline Intra-group & 161.066 & 421 & .383 & 6.706 & $0.000^{*}$ \\
\hline Total & 173.893 & 426 & & & \\
\hline \multicolumn{6}{|c|}{ Non-financial Incentives } \\
\hline Intergroup & 5.960 & 5 & 1.192 & & \\
\hline Intra-group & 123.743 & 423 & .294 & 4.055 & $0.001 *$ \\
\hline Total & 129.702 & 428 & & & \\
\hline \multicolumn{6}{|c|}{ Job Satisfaction } \\
\hline Intergroup & 3.618 & 5 & .724 & & \\
\hline Intra-group & 114.165 & 421 & .272 & 2.662 & $0.022 *$ \\
\hline Total & 117.783 & 426 & & & \\
\hline
\end{tabular}

\section{Conclusion}

According to the findings of the study, the attitudes on financial incentives (3.47) are found to be lower than non-financial incentives (3.54). Besides, the mean of job satisfaction is close to the mean of financial and non-financial incentives (3.52). In accordance with these findings, it is argued that financial incentives used in food chain premises are required a revision. A high-level positive and significant relation is determined between financial incentives used in food chain premises and job satisfaction levels of employees (H1 Accepted). Accordingly, it can be argued that the more positive attitude towards financial incentives, the more the job satisfaction increases. A high-level positive and significant relation is determined between non-financial incentives used in food chain premises and job satisfaction levels of employees (H2 Accepted). Accordingly, it can be argued that the more positive attitude towards non-financial incentives, the more the job satisfaction increases. Besides, it is concluded that the attitudes towards financial incentives have a stronger effect on job satisfaction than non-financial incentives when the results obtained from the tests, which tested the relation between attitudes towards incentives and job satisfaction (H3 Accepted).

Various results have been obtained when it is tested if attitudes towards incentives and job satisfaction of employees at food chain premises differ in accordance with some demographical characteristics. There is also no significant difference on financial incentives in terms of union membership status of employees (H4 Rejected), but there is a significant difference on non-financial incentives in terms of union membership status of employees (H5 Accepted). Accordingly, it is seen that the attitudes of employees with a union membership towards financial incentives have a more positive effect when compared to the ones without a union membership. Therefore, union membership status does not affect the attitudes towards financial incentives, but does affect the attitudes towards non-financial incentives. According to this, it can be argued that there is a higher expectation towards non-financial incentives for those without a union membership. Besides, a test is also made to see the difference at job satisfaction levels in terms of union membership status, but no significant change is observed (H6 Rejected).

A significant difference is determined on the attitudes of employees working at food chain premises towards financial incentives in terms of gender ( $\mathrm{H} 7$ Accepted). According to the findings obtained, the attitudes of male employees towards financial incentives are more positive than female ones. No significant difference is determined on the attitudes of employees working at food chain premises towards non-financial incentives in terms of gender (H8 Rejected). The attitudes of employees towards job satisfaction levels of employees have a significant difference in terms of gender (H9 Accepted). According to this, the job satisfaction levels of female employees are higher than the male ones. Besides, a difference is also observed in the study in terms of income level on the attitudes of employees working at food chain premises and job satisfaction. According to the findings obtained, the attitudes of employees towards financial incentives (H10 Accepted), the attitudes towards non-financial incentives (H11 Accepted) and job satisfaction levels (H12 Accepted) have a significant difference in terms of income level. The attitudes and job satisfaction levels of employees with the lowest income and the ones with the highest income towards incentives differ when compared to others. 
There are also some limitations in the study. First of all, the food chain premises running only in the Central Anatolia Region is taken as context, which is one of the seven regions in Turkey. Only 11 of chain premises accepted to be a part of this study and are taken as sample in this context. Moreover, some of the employees at these premises did/could not participate into the survey due to such reasons as unwilling personnel, who stated the load of work and lack of time to fill in the surveys, or to be on annual leave, therefore being absent at the work place, etc. Taking a larger context as a base and conducting the survey to a broader population will increase the generalizability of the findings obtained from this study. However, this was impossible in our study due to time and cost and regarded as a limitation. The results obtained from the study give very significant data for top managements at food chain premises for revising the incentive policies and directing the public relations policies, etc.

\section{References}

Ağırbaş İsmail, Çelik Yusuf, \& Büyükkayıkçı Hüseyin. (2005). Motivasyon araçları ve iş tatmini: Sosyal Sigortalar Kurumu Başkanlığı hastane başhekim yardımcıları üzerinde bir araştırma. Hacettepe Sağllk İdaresi Dergisi, 8(3), 325-348.

Al-Angari Abdulla bin Abdul Aziz bin Abdul Rahman. (1999). Incentives system and their role in promoting the standard of work performance. (Master Thesis). Naif Arab University for Security Sciences, Saudi Arabia.

Al-Johani Abdullah bin Sulaman. (1997). Evaluation of incentive system according to employees opinion: A field study on Immigration Department at Jeddah. (Master Thesis). Naif Arab University for Security Sciences, Saudi Arabia.

Al-Nsour Marwan. (2012). Relationship between incentives and organizational performance for employees in the Jordanian Universities. International Journal of Business and Management, 7(1), 78-89.

Alwabel, A. (2005). The role of financial and moral incentives on raising the performance level of employees from the viewpoint of the security officers involved in the pilgrimage season. (Master Thesis). Naif Arab University for Security Sciences, Saudi Arabia.

Al-Wathnani Awadh Mohanned Gallab. (1998). Impact of incentives on the efficiency of work performance and job satisfaction in security organizations. (Master Thesis). Naif Arab University for Security Sciences, Saudi Arabia.

Arnolds Ca, \& Venter Djl. (2007). The strategic importance of motivational rewards for lower-level employees in the manufacturing and retailing industries. SA Journal of Industrial Psychology, 33(3), 15-23.

Burgess Simon, \& Ratto Marisa. (2003). The role of incentives in the public sector: Issues and evidence. Oxford Review of Economic Policy, 19(2), 285-300. http://dx.doi.org/10.1093/oxrep/19.2.285

Coşkun Selim, \& Dulkadiroğlu Hakan. (2009). Ücret, performansa göre ücret ve çalışanların algısı: ABD’de federal düzey örneği. Ankara Üniversitesi Siyasal Bilgiler Fakültesi Dergisi, 64(3), 73-95.

Ellis Lorinda, \& Pennington Steuart. (2004). Should leaders have tusks or fangs? Management Today, 20(9), 32-33.

Grossman Sanford, J., \& Hart Oliver, D. (1982). Corporate financial structure and managerial incentives: The economics of information and uncertainty (Editor: John McCall, ed.). UMI, 107-140.

Hermalin Benjamin, E., \& Weisbach Michael, S. (1991). The effects of board composition and direct incentives on firm performance. Financial Management, 20(4), 101-112. http://dx.doi.org/10.2307/3665716

Hillman Alan, L. (1987). Financial incentives for physicians in HMOs. The New England Journal of Medicine, 317, 1743-1748. http://dx.doi.org/10.1056/NEJM198712313172725

Kaya İlke. (2007). Otel işletmeleri işgörenlerinin iş tatminini etkileyen faktörler: Geliştirilen bir iş tatmin ölçeği. Anadolu Üniversitesi Sosyal Bilimler Dergisi, 7(2), 355-372.

Kitapçı Hakan, \& Sezen Bülent. (2002). Çalışanların tatminini belirleyici unsurlar üzerine bir araştırma: Kariyer süreci örneği. Firat Üniversitesi Sosyal Bilimler Dergisi, 12(1), 219-230.

Luthans, F. (1998). Organizational behavior. Singapore: McGraw-Hill.

McDonald Ruth, Harrison Stephen, Checkland Kath, Campbell Stephen, M., \& Roland Martin. (2007). Impact of financial incentives on clinical autonomy and internal motivation in primary care: Ethnographic study. British Medical Journal, 334, 1357-1359. http://dx.doi.org/10.1136/bmj.39238.890810.BE 
Naldöken Ümit, Ekinci Hasan, \& Biçer Enis, B. (2011). Bir devlet hastanesinde ek ödeme yapılmasının işgören motivasyonu üzerindeki etkileri. C.Ü. Íktisadi ve İdari Bilimler Dergisi, 12(2), 283-295.

Öztürk Zekai, \& Dündar Hakan. (2003). Örgütsel motivasyon ve kamu çalışanlarını motive eden faktörler. C.Ü. Íktisadi ve İdari Bilimler Dergisi, 4(2), 57-67.

Pınar İbrahim, Kamaşak Rıfat, \& Bulutlar Füsun. (2008). İş tatmini oluşturan boyutların toplam tatmin üzerindeki etkilerinin doğrulayıcı faktör analizi ile incelenmesi üzerine Türk işletmelerinde bir araştırma. İstanbul Üniversitesi İşletme Fakültesi Dergisi, 37(2), 151-166.

Pouliakas Konstantinos. (2008). Pay enough, don't pay too much or don't pay at all? An empirical study of the non-monotonic impact of incentives on job satisfaction. IZA Discussion Paper No. 4713, http://papers.ssrn.com/sol3/papers.cfm?abstract_id=1545140.

Ryan Peter, J., Henin Claude, G., \& Gandhi Devinder, K. (1986). Financial incentives for cost control under moral hazard. Omega, 14(3), 221-231. http://dx.doi.org/10.1016/0305-0483(86)90041-1

Scheepers Retha. (2009). Shaping corporate entrepreneurship capability: The impact of rewards. AGSE 2009, 107-119.

Solt Michael, E., \& Miller Norman, G. (1985). Managerial incentives: Implications for the financial performance of real estate investment trusts. Real Estate Economics, 13(4), 404-423. http://dx.doi.org/10.1111/1540-6229.00362 